\title{
A NOTE ON ROMANS 6:5: \\ THE REPRESENTATION (ÓMOÍRMA) OF HIS DEATH
}

\author{
Sorin Sabou
}

\begin{abstract}
Summary
The meaning and especially the reference of the öroi $\omega \mu \alpha$ in Romans 6:5 is a subject of debate in Pauline studies. This note, keeping in view the two main lines of interpretation ('corresponding reality' and 'form'), argues for a specific different meaning, namely, that of 'representation' referring to a discourse which here in Romans is the proclamation of the death and resurrection of Christ. It does so by giving an important place to the role of the gospel at the start and in the time of 'newness of life'.
\end{abstract}

\section{Introduction}

In Romans 6:5 there is a puzzling affirmation about Christ's death: 'the likeness of his death'. Different English translations tried to deal with this in different ways; what is translated in KJV as '[ $\mathrm{f}$ ] been planted together in the likeness of his death, [...]', is translated by NRSV, '[f]or if we have been united with him in a death like his, [...]', and the same text becomes in REB, '[f]or if we have become identified with him in his death, [...]'. This note tries to discuss the questions implied in this text and intends to propose a clearer/different meaning and reference to this expression.

From the all occurrences of o $\mu$ ot $\omega \alpha \alpha \alpha$ in the LXX (Exod. 20:4; Deut. 4:12, 15, 16, 17, 18, 23, 25; 5:8; Josh. 22:28; Judg. 8:18; $1 \mathrm{Kgs}$ 6:5, 5; 4 Kgs. 16:10; 2 Chr. 4:3; Ps. 105 (106).20; 143 (144).12; Cant. 1:11; Sir. 31 (34):3; 38:28; Isa. 40:18, 19; Ez. 1:4, 5, 16, 22, 26; 2:1 (1:28); 8:2, 3; 10:1, 8, 10, 21, 22; 23:15; Dan. LXX 3:25 (92); 1 Macc. $3: 48$ ), the example from Deuteronomy $4: 11-25$ is representative and will be discussed at various stages in the argument. 
From the extrabiblical Greek the occurences in Plato, Parm. 132d, 133d; Soph. 266d; Crat. 434a; Aristotle, Metaph. 985b, 986a; Rhet. I.2. 1356a, 31, can be of some help and will be discussed later. The occurrences from inscriptions (Egypt: Hibis 52; OGIS 52; Prose 52) and papyri (ChrWick 1:21; OMich 32; PCair 1:10; PFamTebt 4:98; POxyHels 2;) because are fragmentary, and for this very short, do not contribute to the ellucidation of meaning.

With the exception of Revelation 9:7 this term occurs in NT only in the Pauline Corpus: Romans 1:23 (referring to idols which 'resemble' a mortal human being or a bird); 5:14 (a reference to the sins which were committed in the period between Adam and Moses when there was not a law in place and so these sins were not 'like' the sin of Adam which was a trespass of a command); 8:3 (the Son of God was sent in the 'likeness' of the sinful flesh; this points to the fact that the 'sinful flesh' imposed a particular 'way of existence' in the world and the Son came and shared in it); Philippians 2:7 (Christ was born in 'human likeness', meaning that he was a man).

The meaning and reference of this term depends on the context against which it is interpreted. Every interpretation has to be able to defend a particular line of enquiry on the basis of other relevant ideas from this letter and/or from other letters from Pauline Corpus. The argument of this note is organised in two parts: a) a critical analysis of the contemporary positions and b) in the light of the present research a different understanding will be proposed.

\section{An Overview of the Present State of Research}

\subsection{A 'Corresponding Reality'}

The most detailed study is that of U. Vanni, "O $\mu$ oí $\omega \mu \alpha$ in Paolo'. He argues for an understanding of ópoí $\omega \mu \alpha$ against the linguistic context of LXX. ${ }^{1}$ In LXX he says that the meaning is the 'expressionrepresentation of a reality'. ${ }^{2}$ Vanni interprets Romans 6:5 as follows:

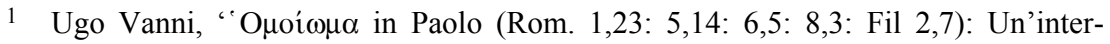
pretazione Esegetico-Theologica Alla Luce Dell'uso Dei LXX, 1a Parte', Gregorianum 58 (1977): 345.

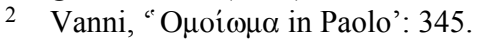


The context of Rom. 6:5 analysed in its temporal aspects, emphasizes baptism as a past fact, eschatological life as a future fact, and the present as a commitment which unites past and future. In such a context $\tau \hat{\omega}$ o $\mu$ ot $\omega \alpha \tau \imath$ expresses the concrete visibility in the Christian of both death and resurrection of Christ. One can interpret the passage in this way: 'If in fact we became and remain dynamically united (to him) because of the palpable expression (in the rite of baptism and then in the life that follows) of his death, then we will certainly (be united to him) also (in the palpable expression which takes place in the immediate future and culminates in the eschatological phase) of the resurrection'. ${ }^{3}$

The reference of o $\mu$ oi $\omega \mu \alpha$ in Romans 6:5 is not so much to what is 'in' the Christian, even if $\sigma 0 \dot{\mu} \phi v \tau o \zeta$ is there in 6:5a, but rather to ó $\mu$ oí $\omega \mu \alpha$ of Christ's death with which the believers are 'united'. The texts speaks of 'being one with the ó $\mu$ oí $\mu \alpha \alpha$ of Christ's death' not because of it. Also it is not clear that the 'palpable' element has to be introduced in the interpretation of this text.

J. D. G. Dunn understands it as meaning 'the convert's experience of death to sin and life beginning to work out in himself, which Paul characterizes as a sharing in Christ's death and so as an experience which is the mirror image and actual outworking of Christ's own death to sin within the present age (6:10)' ${ }^{4}$ His discussion on the meaning of o $\mu$ oi $\omega \mu \alpha$ concludes that it denotes 'the form of transcendent reality perceptible to man. ${ }^{5} \mathrm{He}$ argues for this especially on the basis of Plato, Parmenides 132D and Phaedrus 250B, texts where the 'finite things

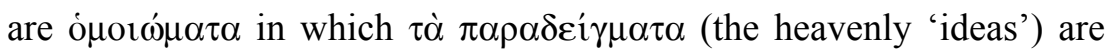
expressed;' 6 the other texts being from the LXX (Exod. 20:4; Deut. $4: 12,15 ; 5: 8$; etc. $)^{7}$ He applies this meaning to Romans $6: 6$ saying that the believer has been fused together with 'the reality of Christ's epochending, sin's dominion-breaking death, in its outworking in the here and now, Christ's death to the extent that it can be experienced and is effective within the still enduring epoch of Adam.' Dunn brings together the meaning of those texts in which ó $\mu$ oi $\omega \mu \alpha$ is used in reference to 'idols' (LXX Deut. 4:16-18, 23, 25; Ps. 106:20; Rom.

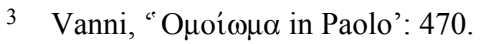

4 J. D. G. Dunn, 'Paul's Understanding of the Death of Jesus as Sacrifice', in S. W. Sykes, ed., Sacrifice and Redemption: Durham Essays in Theology (Cambridge: CUP, 1991): 37.

5 J. D. G. Dunn, Romans (Waco: Word, 1988): 317; also James R. Edwards, Romans (Peabody, Mass.: Hendrickson, 1992): 161-62.

6 Dunn, Romans; 317.

7 Dunn, Romans: 317.

8 Dunn, Romans: 317. 
1:23; etc) with those referring to the form of transcendental realities, by saying that 'however mistakenly, an idol was intended to give concrete representation to spiritual and transcendental realities. ${ }^{9}$ Thus the basic outlook of Dunn's position is the idea of 'likeness' 10 which helps him to integrate both those main kind of texts: those which refer to idols, images and those which refer to transcendental realities. It is on the meaning and relevance of these two kind of texts that the debate developed.

Ridderbos explains it by saying that the 'likeness' is 'a redemptivehistorical likeness by virtue of its oneness with Christ' 11 and in this way interpreting 'likeness' against the group of texts in which the 'corresponding transcendental realities' are in view.

Fitzmyer says that ó $\mu$ oí $\omega \alpha$ 'denotes not merely the abstract idea of 'likeness', but the concrete image that is made to conform to something else (cf. LXX - Exod. 20:4; Deut. 4:16-18; 5:8)' ${ }^{12}$ The reference is 'to baptismal washing as the means of growing together; that means is baptism, a likeness to Christ's death.' ${ }^{13}$ Also he understands the dative of ómoí $\omega \mu \alpha$ as being a dative of instrument because, he asks, 'can one grow together with a likeness?' 14 The idea of 'conformity to something else' is present because for being able to speak about likeness' with something there have to be some 'common' features in place. But the problem with the identified reference of Fitzmyer's position is that 'the baptism' was not the way in which Christ died (his death was not by drowning). Also 6:5b points to a present aspect of that 'being one with the likeness' (see the perfect $\gamma \varepsilon \gamma o ́ v \alpha \mu \varepsilon v$ ), and if the 'likeness' refers to baptism, is the believer 'still under water' 15 for being able to 'grow into union with him'? ${ }^{16}$ And o $\mu$ oi $\omega \mu \alpha$ has to be supplied also in the second part of 6:5 because of the ellipsis and in this case 'the likeness of the resurrection' cannot refer to something related to a past baptismal rite ('baptism' is not an image of resurrection but an instrument of burial $[6: 4])$.

9 Dunn, Romans: 317.

10 Dunn, Romans: 316.

11 H. N. Ridderbos, Paul, An Outline of His Theology (Grand Rapids: Eerdmans, 1975): 208.

12 Joseph A. Fitzmyer, Romans (New York: Doubleday, 1993): 435.

13 Fitzmyer, Romans: 435.

14 Fitzmyer, Romans: 435.

15 Dunn, Romans: 317.

16 This is Fitzmyer's translation of 6:5a. 
Käsemann observation is helpful here especially because that particular question ('can one grow with a likeness?') asked by Fitzmyer determined him to reach that conclusion (the baptismal washing as the likeness of Christ's death); he says: 'it is in the best interests, therefore, not to cling too closely to the LXX or to postulate a standarized usage but to let the particular context be decisive. ${ }^{17}$ His interpretation is that 'Paul is speaking of the death of Jesus, which is both historical and an eschatological event, and which cannot be fixed to a single time alone but concerns the whole world. [...] o $\mu$ oi $\omega \mu \alpha$ [...] distinguishes from the event of Golgotha as much as it connects with that event'. ${ }^{18}$ Thus he is close to Ridderbos' position.

Another scholar which argues on the line of meaning of ritual is H. D. Betz. He says that Paul's choice of $\sigma \dot{v} \mu \phi v \tau o \varsigma$ and ó $\mu$ oí $\omega \mu \alpha$ was intended 'to illuminate two essential problems raised by rituals in general. The first term $\sigma u ́ \mu \phi v \tau o \zeta$, states the effect the ritual has, while the second, ó $\mu$ oi $\omega \mu \alpha$, determines the relationship between the image of something and that something itself.' ${ }^{\prime 19}$ Betz continues

it seems obvious that o $\mu o \dot{\omega} \omega \mu \alpha$ is an abstractum referring to baptism. Given the lexicological background of the term ó $\mu$ oi $\omega \mu \alpha$ and its main synonyms ( $\varepsilon i \kappa \omega ́ v, \mu i \mu \eta \mu \alpha$ ), the usage in v. 5 intends, it seems, the ritual as ritual: this ritual is a o $\mu$ oi $\omega \mu \alpha$. Indeed other terms would not be

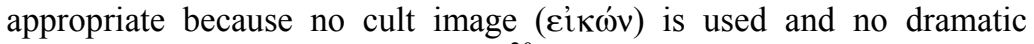
episodes $(\mu \mu \eta \eta \dot{\eta} \mu \tau \alpha)$ are performed. ${ }^{20}$

In relation to this position it has to be said that it is not clear that a

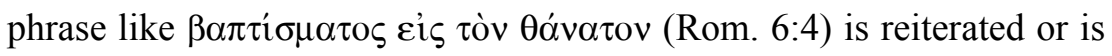

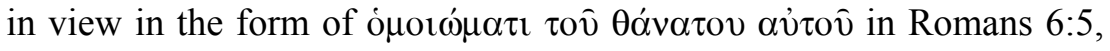
for being able to say that 'the effects of the ritual' are in view in Romans 6:5. And the choice of $\sigma 0 \dot{\mu} \phi v \tau o \varsigma$ does not point to the 'effects' of the ritual but to 'the kind of relationship' which is in view, namely 'a close relationship', a 'being one with', which is available. Even the text from Dio Chrysostom to which Betz refers in the note 112 (p. 115) does not point to the 'effects' but to the fact that those men were in a close relationship with the divine

17 E. Käsemann, Commentary on Romans (Grand Rapids: Eerdmans, 1980): 167.

18 Käsemann, Romans: 168.

19 Hans Dieter Betz, 'Transferring a Ritual: Paul's Interpretation of Baptism in Romans 6', in Troels Engberg-Pedersen, ed., Paul in His Hellenistic Context (Edinburgh: T\&T Clark, 1994): 114.

20 Betz, 'Transferring': 115. 
for inasmuch as these earlier men were not living dispersed far away from the divine being or beyond his borders apart by themselves, but had grown up ( $\pi \varepsilon \phi \cup \kappa o ́ \tau \varepsilon \varsigma)$ in the very centre of things, or rather had grown up in his company and had remained close to him in every way ( $\mu \hat{\alpha} \lambda \lambda \mathrm{ov}$

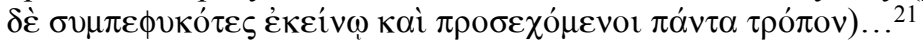

\subsection{A 'Form'}

The 'form' line of investigation is defended by R. Tannehill and others (Cranfield, Moo, Schreiner). He says that 'being united with the óoi $\omega \mu \alpha$ of Christ's death is not restricted to the past rite, but is something which is characteristic of the continuing existence of the Christian.' ${ }^{22} \mathrm{He}$ says that in LXX there are two basic meanings for ó $о$ í $\omega \mu \alpha:$ 'copy' or 'image' and 'form'.

o $\mu$ oi $\omega \mu \alpha$ indicates the form of the reality itself in its outward appearance, rather than a second thing which is similar to this reality. [...] Rom. 6:5 does not refer to the union of the believers with a 'likeness' of Christ's which is distinct from that death, but rather speaks of a direct union with Christ's death. ${ }^{23}$

In answering the question 'why does Paul speak of the 'form' of Christ's death rather than speaking simply of his death?' Tannehill points to Philippians 2:7 where ómoí $\omega \mu \alpha$ 'is used to describe the existence of Christ after self-emptying. ${ }^{24}$ Paul used this term in Romans 6:5, says Tannehill,

because the death and resurrection are connected with the two 'forms' of Christ existence, the earthly existence of the one who was subject to the powers and the heavenly existence of the exalted Lord. The use of ómoi $\omega \mu \alpha$ in Rom. 6:5 reflects this idea of conformation to Christ (Phil. $3: 21 ; 3: 10)$. It adds to the thought of this verse in that it suggests that Christ's death and resurrection are continuing aspects of the 'form' of Christ and that the death and resurrection of Christ are present to the

21 Dio Chrysostom, Discourses 12:28 (J. W. Cohoon, tr.; Cambridge, MA, London: Harvard University Press, William Heinemann, 1939): 2.30-31

22 Robert C. Tannehill, Dying and Rising with Christ: A Study in Pauline Theology (Berlin: Verlag Alfred Töpelman, 1967): 34.

23 Tannehill, Dying: 35; for another position which argues for the fact that the 'likeness of his death' characterizes the death of Christ' see Günther Bornkamm, 'Baptism and New Life in Paul (Romans 6)', in Early Christian Experience (London: SCM, 1969): 77, and A. Schlatter, Romans: The Righteousness of God (S. S. Schatzmann, trans.; Peabody, Mass.: Hendrickson, 1995): 149.

24 Tannehill, Dying: 35. 
believers in transforming power, so that the believers take on the same 'form'. ${ }^{25}$

This line of interpretation is able to integrate the 'form' of Christ's death (by crucifixion; Rom. 6:6) in the general line of the argument. Also it points to the theme of the section 'death to sin' by its reference to the language of transformation by the 'form' of Christ's death. What is not clear is why $\sigma u ́ \mu \phi v \tau o \varsigma$ and ó $\mu$ oi $\omega \mu \alpha$ have to be treated almost like synonymous; these two terms have their role in Paul's argument and that has to be defined as clear as possible. Paul does not use $\mu о \rho \phi \eta$, but óoí $\omega \mu \alpha$ (the point is not the 'form' of Christ's existence [Phil. 2:7], but something about his death and it is not clear that the specific point in view in 6:5 is on the 'form' of Christ's death) and it is better first to take into consideration all the available relevant texts before choosing one background or another. For being accepted a interpretation has to able to explain satisfactorily the existence of this lexeme here.

\subsection{A 'Representation' of his Death}

Here in Romans 6:5 Paul speaks about Christ's death. The historical aspect of that event is in view in the sense that Christ experienced it. The basic question is how has that event to be viewed here? The most probable view is that this event is mentioned as a part of early Christian proclamation. Every one who was not an ocular witness knew about this event because someone else has told him about it (see Rom. 10:1415). This basic observation is our starting point for defending a different interpretation of ó $\mu$ oi $\omega \mu \alpha$ in 6:5 than those presented above.

In relation to syntax of the phrase, 'taking the genitive ( $\tau 0 \hat{v}$

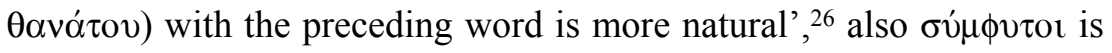
more natural to be followed by $\tau \hat{\emptyset}$ ó $\mu$ ot $\omega \mu \alpha \tau$ (a dative following a $\sigma v v^{-}$word) $;^{27}$ the dative is interpreted as associative ${ }^{28}$ (a translation of

25 Tannehill, Dying: 39; also C. E. B. Cranfield, A Critical and Exegetical Commentary of the Epistle to the Romans (vols 1 and 2; Edinburgh: T. \& T. Clark, 1975 \& 1979): 308; for a recent defence of this position see Douglas J. Moo, The Epistle to the Romans (Grand Rapids: Eerdmans, 1996), pp. 369-71, and Thomas R. Schreiner, Romans (Grand Rapids: Baker Books, 1998): 314.

26 F. Blass and A. Debrunner, A Grammar of the New Testament and Other Early Christian Literature (tr. Robert W. Funk; Cambridge; Chicago: CUP; University of Chicago Press, 1961): 104, § 194.

27 Also Rudolf Schnackenburg, Baptism in the Thought of St. Paul: A Study in Pauline Theology (tr. by G. R. Beasley-Murray; Oxford: Basil Blackwell, 1964): 46; 
6:5 being 'if we have been united with the likeness of his death we will be also [united with the likeness] of [his] resurrection').

In Romans 6:3-5 the reference is to the beginning of the Christian life (see the language of 'baptism'). The beginning of such a life is related to hearing the gospel which is proclaimed (see especially Rom. 10:6-15; Gal. 3:1-3). The response or the attitude of those who are reffered to being Christians is that of 'believing' what was proclaimed (Rom. 10:13-14; Gal. 3:3; also 1 Cor. 15:1-6). The death of Christ was part of that proclamation (Gal. 3:1-2; 1 Cor. 15:3). The evidence from Galatians 3:1 is important for understanding Romans 6:5. That text says something about the way in which Paul proclaimed the gospel and the specific point is in relation to the way in which Christ's death was proclaimed: Christ was 'portrayed' ( $\left.\pi \rho \gamma_{\rho} \alpha \dot{\phi} \omega\right)$ as crucified; it was a vivid verbal description. ${ }^{29}$ The relevant point of this for our investigation is that this event was made 'present' before of their eyes, or, as Betz puts it, was 'so vividly and so impressively that his hearers imagined the matter to have happened right before their eyes. ${ }^{3} 0$

Now the important question is whether there are any occurences in the available Greek literature which would allow us to say that a discourse or a presentation of some action was referred to as ó $\mu$ oi $\omega \mu \alpha$. If that is the case, one of the main lines of argumentation in Romans,

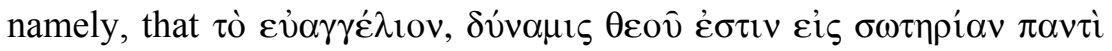

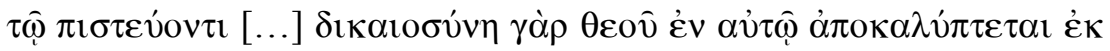

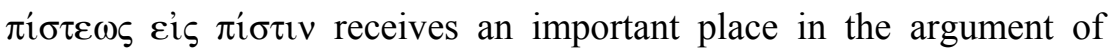
Romans 6. Paul says that the act of proclamation of the gospel is an event of revelation. The saving righteousness of God is revealed in what he did in the death and resurrection of Christ. That proclaimed 'story/image' of God's salvation of humankind accomplished in the death and resurrection of Christ is the event with which they are 'united'. In other words those saving events are proclaimed and what

Moo, Romans: 368; Schreiner, Romans, pp. 314, 315; Cranfield, Romans: 307; Hans Dieter Betz, 'Transferring': 115.

28 Schnackenburg, Baptism: 46; Bornkamm, 'Baptism': 78; Ulrich Wilckens, Der Brief and die Römer (2; Zurich, Neukirchener: Benzinger, 1980): 13; Schreiner, Romans: 315.

29 Johanes P. Louw and Eugene A. Nida, Greek-English Lexicon of the New Testament Based on Semantic Domains (New York: United Bible Societies, 1988, 1989): 410; see the discussion in J. Louis Martin, Galatians (New York: Doubleday, 1997): 283; Neil Elliot, Liberating Paul: The Justice of God and the Politics of the Apostle (Sheffield: Sheffield Academic, 1995): 93.

30 Hans Dieter Betz, Galatians (Philadelphia: Fortress, 1979): 131. 
was accomplished then it is revealed now (see the present tense in 1:17). ${ }^{31}$ Also, see here the reference from the Romans 6:17-18 where the releasing from dominion of $\sin$ is the result of the obedience from the heart to 'the pattern of teaching'.

Indeed there are Greek texts in which o $\mu$ oi $\omega \mu \alpha$ is used with the sense of a 'representation', which refer either to a discourse, a melody, or a drama. Two texts are especially relevant for our enquiry. First, Aristotle, Politics 1340a-b:

And since it is the case that music is one of the things that give pleasure, and that virtue has to do with the feeling, delight and love and hatred rightly, there is obviously nothing that is more needful to learn and become habituated to than to judge correctly and to delight in virtuous characters and noble actions; but rhythms and melodies contain representations (o $\mu \mathrm{ot} \omega \mu \alpha \tau \alpha)$ of anger and mildness, and also of courage and temperance and all their opposites and the other moral qualities, that most closely correspond to the true nature of these qualities (and this is clear from the facts of what occurs when we listen to such representations we change in our soul); and habituation in feeling pain and delight at representations ( them towards actual reality (for example, if a man delights in beholding the statue of somebody for no other reason than because of its actual form, the actual sight of the person whose statue he beholds must also of necessity give him pleasure); and it is the case that whereas the other objects of sensation contain no representation (oj $\mu$ oi $\omega \mu \alpha)$ of character, for example the objects of touch and taste (though the objects of sight do so slightly, for there are forms that represent character, but only to a small extent, and not all men participate in visual perception of such qualities; also visual works of art are not representations (o $\mu$ ot $\omega \mu \alpha \tau \alpha)$ of character but rather the forms and colours produced are mere indications of character, and these indications are only bodily sensations during the emotions; not but what in so far as there is a difference even in regard to the observation of these indications, the young must not look at the works of Pauson but to those of Polygnotus, and of any other moral painter or sculptor), pieces of music on the contrary do actually contain in themselves imitations of character; [1340b] and this is manifest, for even in the nature of the mere melodies there are differences, so that people when hearing them are affected differently and have not the same feelings in regard to each of them, but listen to some in a more mournful and restrained state, for instance the mode called Mixolydian, and to others in a softer state of mind, but in a midway state and with the greatest composure to another, as the Dorian mode alone of tunes seems to act, while the Phrygian makes men enthusiastic; for these things are well stated by those who have studied this form of education, as they

31 See the discussion in Dunn, Romans: 43; Moo, Romans, pp. 69-70. 
derive the evidence for their theories from the actual facts of experience. ${ }^{32}$

From this text it is clear that a o $\mu$ oi $\omega \mu \alpha$ (a 'representation' of anger, mildness, courage, temperance and all their opposites and other moral qualities) can change the soul of a hearer or viewer of it. There are different grades of perception and the viewers/hearers are affected differently. The next text refers exactly at this aspect of 'impact' and tries to 'exemplify' one of the comments from the quoted text ('the young must not look at the works of Pauson but to those of Polygnotus, and of any other moral painter or sculptor' [our italics]). The text is from Plato, Laws, 812b:

Ath. After the writing-master, must we not address the lyre-master?

Clin. Certainly.

Ath. When assigning to the lyre-master their proper duties in regard to the teaching training in these subjects, we must, as I think, bear in mind our previous declarations.

Clin. Declarations about what?

Ath. We said, I fancy, that the sixty-year old singers of hymns to Dionysus ought to be exceptionally keen of perception regarding rhythms and harmonic compositions, in order that when dealing with musical representations of a good kind or a bad, by which the soul is emotionally affected, they may be able to pick out the reproductions

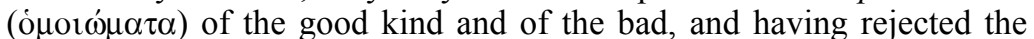
latter, may produce the other in public, and charm the souls of the children by singing them, and so challenge them all to company them in acquiring virtue by means of these representations. ${ }^{33}$

So, a melody, a discourse was called ó $\mu$ oí $\omega \mu \alpha$ because it 'represented' something (a feeling, an action, character); the issue was that this o $\mu$ oi $\omega \mu \alpha$ affected the hearer/viewer, that is why the above text speaks about the protection of the hearers/viewers by presenting them only the ó $\mu$ ot $\mu \alpha \tau \alpha$ of a good kind, for charming their souls.

So the interpretation argued for in this project is that 'the gospel is the power of God for salvation' based on the fact that when someone heard it being proclaimed (proclamation which is referred here as ó $\operatorname{cí} \omega \mu \alpha)$ and believed it he 'was changed in the soul'. Paul uses the

32 Aristotle, Politics (tr. H. Rackham; Cambridge, MA; London: Harvard University Press, 1944).

33 Plato, Laws (II; tr. R. G. Bury; Cambridge, MA; London: Harvard University Press; William Heinemann, 1984). 
expression 'they were united with' what was proclaimed, they 'coalsesced' with what they heard; the accent being on the 'death of Christ'. In other words, the proclamation of the gospel ('the disclosure' of God's salvation in Christ's death) is a 'representation' of Christ's death and resurrection. Paul says that both events are 'present' for being united with. But between them there is this relation: if they 'are one' with what was proclaimed about Christ's death they 'will be one' with what was proclaimed about his resurrection. The idea is not that 'death' is a present reality and 'resurrection' is a future one, but that if the first is in place the second has to be there also. This is not called 'resurrected' life but 'newness of life'. The interpretation of the

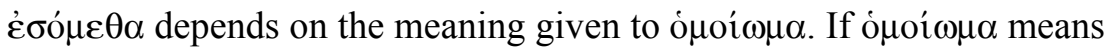
'corresponding reality' or 'form' the future is understood as eschatological: only then the believers will be united with the 'corresponding reality' (Dunn) or 'form' (Tannehill) of the resurrection. ${ }^{34}$ But if ó $\mu$ oí $\omega \alpha \alpha$ means 'representation' and refers to the proclamation of death and resurrection of Christ then that event is believed, that is, they are 'coalesced' with it and as Christ was raised from the dead they walk in the newness of life. ${ }^{35}$

Thus, even if the other possibilities for a different meaning and reference to the o $\mu$ oi $\omega \mu \alpha$ are available (see the above positions), the last one is proposed here because it is able to better integrate the fact that Christ's death was a part of the proclamation of the gospel; this event/action of proclamation is at the heart of the starting of Christian life. According to the text which offers the 'theme' of the letter (Rom. $1: 16-17)$, the 'gospel' has a fundamental role in bringing salvation for every one who believes what is proclaimed about what God did in Christ for salvation of humankind. The 'coalescence' with this 'representation' of Christ's death, says Paul, is at the start and is a continuous reality in the life of the believers.

34 See the arguments of Käsemann, Romans: 169; Dunn, Romans: 318; Edwards, Romans: 162; Moo, Romans: 371.

35 See also Fitzmyer who says that 'esometha has to be understood as gnomic, expressing a logical sequel to the first part of the verse', (Romans: 435). 